\title{
The cytogenetic screening of South African artificial insemination bulls
}

\author{
ND Nel *, EJ Harris, JE Weiermans, EHH Meyer \\ Animal and Dairy Science Research Institute, \\ Private Bag X2, Irene, 1675 , Republic of South Africa
}

(Received 20 March 1990; accepted 14 December 1991)

\begin{abstract}
Summary - Following the discovery of the $1 / 29$ chromosome translocation in Swedish artificial insemination (AI) bulls, cytogenetic evaluation of South African AI bulls was initiated. The present paper reports on the 269 bulls screened over the past $11 \mathrm{yr}$. The $1 / 29$ chromosome translocation was found in Brahman and Brown Swiss bulls while chimerism was present in the Friesian bulls. The overall incidence of chromosome abnormalities in these bulls is $1.49 \%$. Although the incidence is low, discovery of the abnormalities serves to illustrate the importance of cytogenetic screening in the AI industry.
\end{abstract}

cattle / chromosome abnormality / translocation / chimerism

Résumé - Le contrôle cytogénétique des taureaux sud-africains d'insémination artificielle. A la suite de la découverte de la translocation chromosomique 1/29 chez des taureaux d'insémination artificielle (IA) suédois, l'examen cytogénétique des taureaux d'IA sud-africains a été entrepris. Cet article concerne les 269 taureaux examinés au cours des 11 dernières années. La translocation chromosomique 1/29 a été trouvée dans les races Brahman et Brune des Alpes, et par ailleurs le chimérisme existe chez les taureaux de race Frisonne. $L$ 'incidence globale des anomalies chromosomiques chez ces taureaux est de 1,49\%. Bien que ce taux soit faible, la découverte de ces anomalies illustre l'importance d'un contrôle cytogénétique pour les centres d'IA.

bovin / anomalie chromosomique / translocation / chimérisme

\section{INTRODUCTION}

Artificial insemination has, since its inception, revolutionised the cattle breeding industry. There is, however, an ever-present danger in its widespread application; undiagnosed genetic defects and less severe chromosome abnormalities may be spread rapidly through the use of a carrier bull's semen. Examples can be found in the amputated calf syndrome present in Friesian cattle (Wriedt and Mohr, 1928; Meyer et al, 1980), the high incidence of the 1/29 chromosome abnormality in Swedish Red and White cattle (Gustavsson, 1969) and inherited immunodeficiency diseases such as agammaglobulinaemia (Perryman, 1979).

* Correspondence and reprints 
These examples illustrate the importance of effective screening procedures for all bulls used in the artificial insemination industry. Present screening techniques are based on pedigree history, progeny testing, semen quality testing, libido, linear trait selection and chromosome analysis.

With the advent of recombinant technology, it will be possible in future to screen for a host of important genetic defects using a battery of defect-specific DNA probes.

Since the discovery of the $1 / 29$ chromosome abnormality in various cattle breeds and its effect on fertility (Refsdal, 1976; Blazak and Eldridge, 1977; Gustavsson, 1979; Kovacs and Csukly, 1980; Popescu, 1977, 1982; Swartz and Vogt, 1983; Foulley and Frebling, 1985), chromosome screening has become an important component of bull evaluation.

Following the discovery of the 1/29 translocation in Swedish AI bulls (Gustavsson, 1969), cytogenetic evaluation of South African AI bulls was initiated in 1977 to ensure that chromosome abnormalities were not spread by the use of carrier bulls.

This paper reports on the cytogenetic study of bulls used in the South African AI industry over the past $13 \mathrm{yr}$.

\section{MATERIALS AND METHODS}

Peripheral blood samples taken from 269 bulls comprising 20 cattle breeds (table I) were submitted for cytogenetic analysis. These samples were taken from bulls stationed at AI centres belonging to the Artificial Insemination Co-operative.

Routine screening was performed on Giemsa-stained metaphase spreads obtained from whole blood cultures. The culture method was adapted from that of Moorhead et al (1960). In this method, concanavalin A $(0.01 \mathrm{mg} / \mathrm{ml})$ was used instead of phytohaemagglutinin. The chromosome spreads were routinely stained in $5 \%$ Giemsa and 10 well dispersed metaphase spreads were screened for structural or numerical aberrations.

The chromosomes of animals found to deviate from the standard karyotype were identified by means of an R-banding technique adapted from Popescu (1975), Popescu et al (1982) and Di Berardino and Ianuzzi (1982).

The lymphocyte cultures were exposed to $5^{\prime} \mathrm{Brdu}(50 \mu \mathrm{g} / \mathrm{ml})$ for $5 \mathrm{~h}$ prior to harvesting. The air-dried, rinsed slides were passed through a series of alcohol grades to water, rinsed in phosphate buffer and stained in acridine orange for $15 \mathrm{~min}$. After rinsing for $30 \mathrm{~min}$, the cells were mounted in a drop of buffer and sealed with nail varnish. Banded metaphase spreads were photographed with Zeiss Epifluorescence equipment on Agfaortho 25 film.

In instances where a chromosome abnormality was found, follow-up studies ascertained the origin and extent of the abnormality in the population.

\section{RESULTS}

A study of the metaphase spreads confirmed the presence of 29 acrocentric autosomal pairs and one pair of sex chromosomes, a large submetacentric X chromosome and a small metacentric Y chromosome in the Bos taurus and Bos indicus (Sanga) bulls. In the $B$ indicus (Zebu) bulls, the $\mathrm{Y}$ chromosome is represented by a small acrocentric chromosome. 
Table I. AI bulls screened.

\begin{tabular}{|c|c|c|c|c|}
\hline Breed & Application & Typ & & $\begin{array}{c}\text { No } \\
\text { of bulls }\end{array}$ \\
\hline Ayrshire & Dairy & Bos taurus & & 16 \\
\hline Brown Swiss & Dairy/Beef & - & & 6 \\
\hline Charolais & Beef & - & & 1 \\
\hline \multicolumn{5}{|l|}{ Devon } \\
\hline (North and South) & Beef & - & & 7 \\
\hline Friesian & Dairy & - & & 108 \\
\hline Guernsey & Dairy & - & & 20 \\
\hline Hereford & Beef & - & & 10 \\
\hline Jersey & Dairy & - & & 19 \\
\hline Pinzgauer & Beef & - & & 7 \\
\hline Red Poll & - & - & & 1 \\
\hline SA Angus & - & - & & 10 \\
\hline Short Horn & - & - & & 2 \\
\hline Simmentaler & - & - & & 12 \\
\hline Sussex & - & - & & 5 \\
\hline Brahman & - & Bos indicus & (Zebu) & 13 \\
\hline Santa Gertrudis & - & - & (Zebu) & 3 \\
\hline Afrikaner & - & - & (Sanga)* & 2 \\
\hline Bonsmara & - & - & $(\text { Sanga })^{*}$ & 26 \\
\hline Drakensberger & - & - & (Sanga)* & 4 \\
\hline Nguni & - & - & (Sanga) $^{*}$ & 2 \\
\hline Total & & & & 269 \\
\hline
\end{tabular}

* Bos indicus (Sanga) cattle are indigenous to Southern Africa.

Screening of the Giemsa stained and subsequent R-banded metaphase spreads revealed the presence of abnormalities in the Friesian, Brahman and Brown Swiss cattle (table II). Giemsa stained and R-banded karyotypes are shown in figures 1 , 2 and 3.

Table II. Chromosome abnormalities in the bulls screened.

\begin{tabular}{lcccc}
\hline & Animals & & \multicolumn{2}{c}{ Abnormality } \\
\cline { 1 - 2 } \cline { 5 - 5 } Breed & Screened & & Type & No \\
\hline Friesian & 108 & & $60, \mathrm{XX} / \mathrm{XY}$ & 2 \\
Brahman & 13 & & $59, \mathrm{XY}, \mathrm{t}(1 ; 29)$ & 1 \\
Brown Swiss & 6 & & $59, \mathrm{XY}, \mathrm{t}(1 ; 29)$ & 1 \\
\hline
\end{tabular}

Following the discovery of the chromosome abnormalities, subsequent studies revealed that the Friesian bulls were both co-twins to heifers and that the Brahman bull was descended from carrier cattle imported from the United States of America. In the case of the Brown Swiss bull, the most recent discovery, the origin has as 


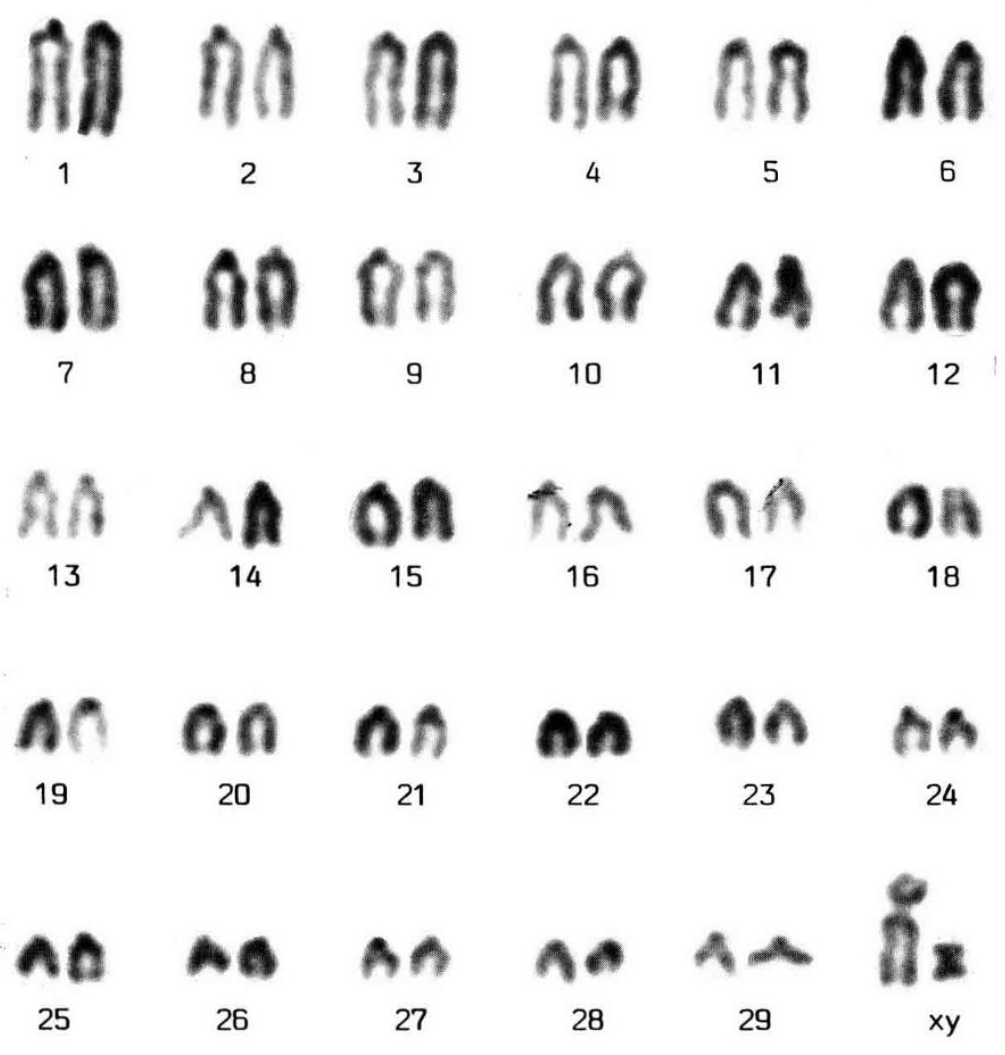

Fig 1. A Giemsa stained karyotype of the $B$ taurus and $B$ indicus (Sanga) bull.

yet not been ascertained but the normal familial pattern of inheritance has been established (results not shown).

\section{DISCUSSION}

The results in table II show that structural chromosome abnormalities appear in one beef and one dual purpose breed, while there is a total absence in the 4 dairy breeds screened. The chimerism that does appear in the Friesian breed cannot be considered a primary chromosome defect. The lack of chromosomal aberrations in the pure dairy breeds is in accordance with the findings of teams across the world (see reviews by Popescu, 1977 and 1982; Gustavsson, 1979; Foulley and Frebling, 1985). Possible reasons for this absence are the pure breeding practices and the constant selection for fertility in these breeds. Any animal which does not meet the required standard, irrespective of the reason, is automatically culled from the production herd. 


\section{nn}

1

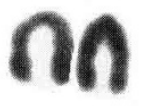

7

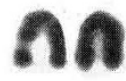

13

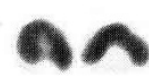

19
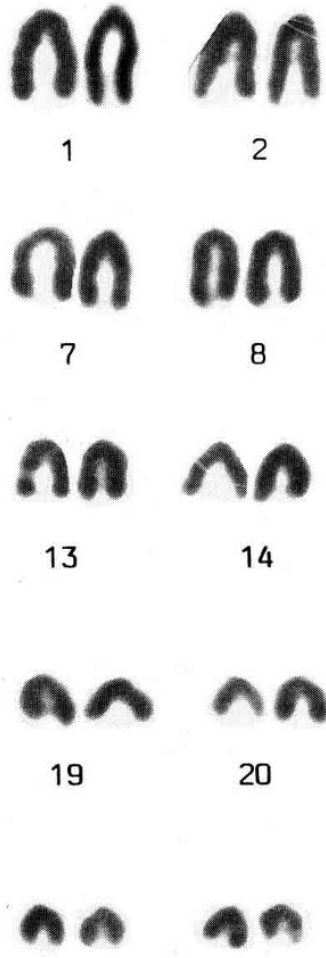

25
2

8

14

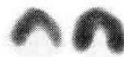

20

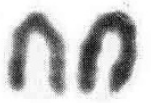

3

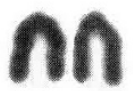

9

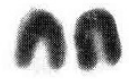

15

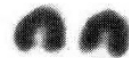

21

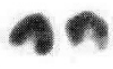

26

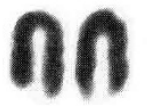

4

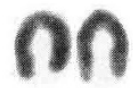

10

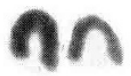

16

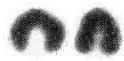

22

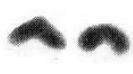

28 nn

5

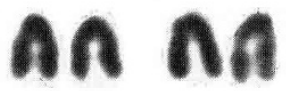

11

12

6

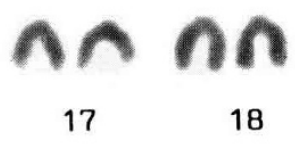

na

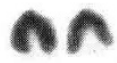

23

24

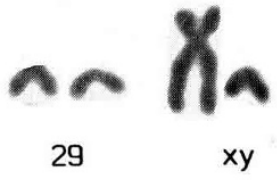

Fig 2. A Giemsa stained karyotype of a $B$ indicus (Zebu) bull.

As the sample sizes are very small, these results do not give any indication of the incidence of the particular abnormality in the national herd. Each case should be investigated individually before such predictions are possible.

The chimerism found in the 2 Friesian bulls was traced to the presence of female co-twins during pregnancy. The observed incidence of $1.85 \%$ ( 2 of the 108 bulls) is slightly higher than the expected figure of $1 \%$ for twins of opposite sex. The average twinning rate in South African Friesian cattle is $2 \%$ (Friesian Cattle Breeder's Society, 1989, unpublished results). This discrepancy is possibly due to the small sample size.

The condition, known as freemartinism in the heifer co-twin, is caused by an allantochorionic anastomosis during embryo development. This condition was described as far back as 1911 (Tandler and Keller, 1911) and has since been studied extensively by Short et al (1969). In South Africa, the condition was first described by Gerneke in 1969. The condition affects the fertility of the heifers and, although some of the bulls may not be affected, infertility has been reported. It is, therefore, advisable to remove such bulls from the selection programme (Dunn et al, 1968; Gerneke, 1969; Short et al, 1969; Stafford, 1972; and unpublished results, Animal and Dairy Science Research Institute). 


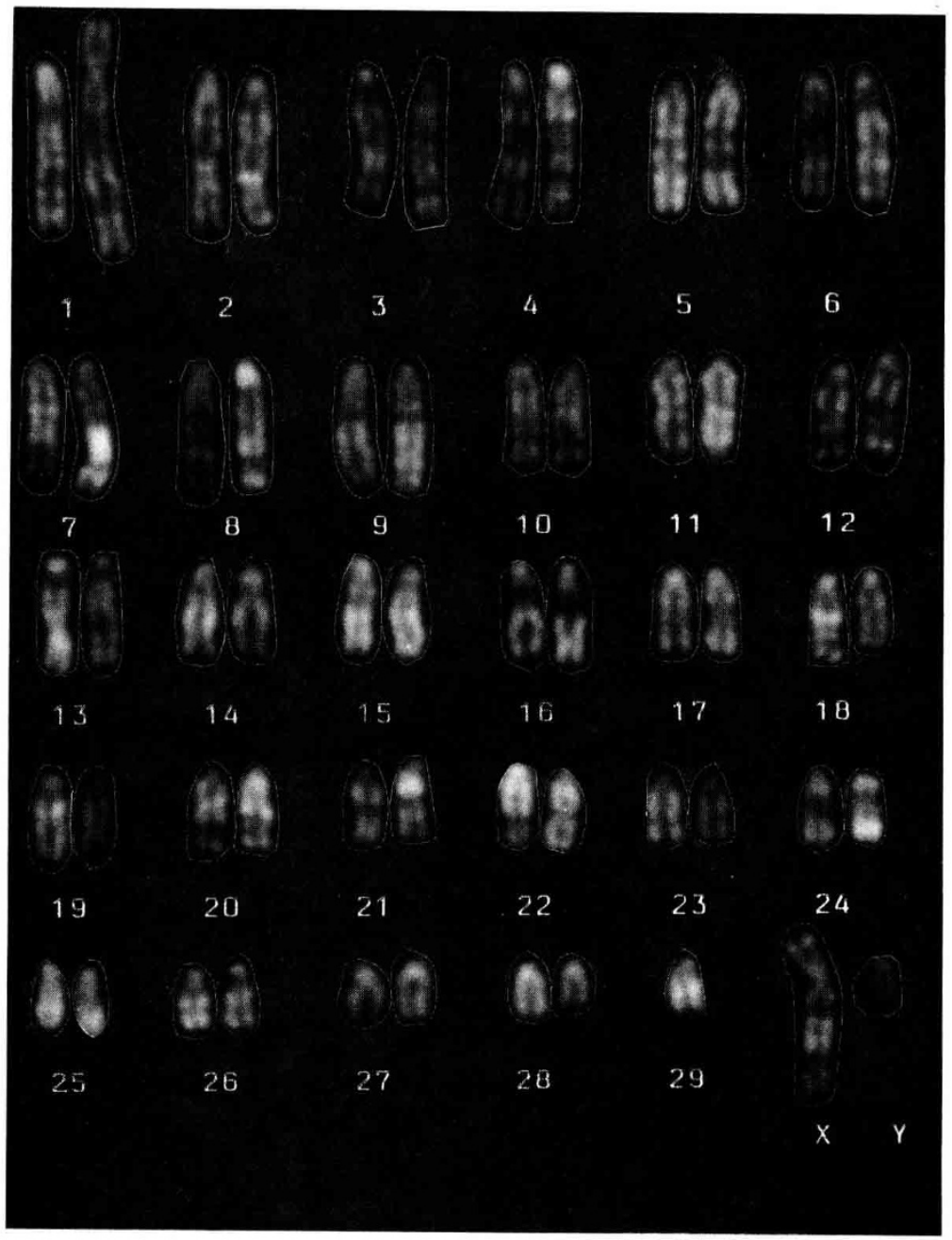

Fig 3. An R-banded karyotype of a $1 / 29$ translocation heterozygote bull ( $B$ indicus Zebu).

The occurrence of twinning in cattle should be carefully monitored during any long-term programme aimed at increasing the fertility of a particular breed. An increase in the twinning frequencies would immediately oppose any gains in fertility and this would necessitate a re-evaluation of the selection programme in use.

The 1/29 chromosome translocation found in the Brahman bull was introduced into the Southern African herd by Brahman cattle imported from the United States of America during the 1960's. The subsequent investigation showed that the anomaly was confined to a particular family and was not present in a random sample of unrelated Brahman cattle (Nel et al, 1988). 
The most recent abnormality found was that in a Brown Swiss bull. The preliminary study shows a familial pattern of inheritance with the translocation present in the dam and maternal half-sister.

During the period 1974-1986, Brown Swiss semen was imported from the United States of America, Austria, West Germany and Switzerland. It is possible that some of this semen may have originated from a carrier bull. Translocation carrying Brown Swiss cattle have been reported in Switzerland and the United States of America. The incidence in these 2 herds is $0.4 \%$ and $2.4 \%$ respectively (Blazak and Eldridge, 1977; Tschudi, 1984). The investigation will continue and the detailed results will be published at a later stage.

It is interesting to note that the $1 / 29$ Robertsonian translocation was not found in the $12 \mathrm{AI}$ Simmentaler bulls tested, despite the fact that the anomaly is present in the South African herd. Tests carried out on 3 stud farms revealed an incidence of $20 \%$ ( 25 of the 125 cattle investigated) in the herds screened (unpublished observations).

As most of the sires used on these farms originated from a single stud herd, it cannot be construed as a national herd average but merely serves as an indication of a higher than average proportion of translocation carrying cattle. Based on the results of Gustavsson (1979) a figure of $\approx 2.7 \%$ would appear to be a reasonable world average. This study has been suspended because of the reluctance of the Simmentaler Breed Society to allow the screening of their cattle.

A similar situation is present in the indigenous Nguni cattle where an incidence of $10.2 \%$ was established in the 305 cattle studied (Nel et al, 1985). After facing near-extinction, attempts are underway to increase the number of Nguni cattle: a culling programme was therefore initiated to ensure that stud animals are free of the 1/29 translocation. No abnormalities were found in the 2 AI bulls screened.

The overall incidence of chromosome abnormalities in South African AI bulls is low, $1.49 \%$ of which only $0.74 \%$ are heritable abnormalities. Nevertheless, the abnormalities found in the bulls screened illustrate the importance of these tests in situations where a specific animal is extensively used, in, for example, artificial insemination and, to a lesser extent, embryo transfer from an elite corps of females.

Cytogenetic laboratories worldwide perform an extremely valuable function and it is imperative that the tests be continued and expanded to include the testing and certification of bulls selected for import and export purposes. The introduction of the 1/29 chromosome translocation into the South African Brahman herd as well as the suspected introduction into the Brown Swiss herd through the use of imported material is indicative of the important role of cytogenetic screening.

\section{ACKNOWLEDGMENTS}

We thank the Taurus Co-operative for their assistance and contribution to this study. We also thank those farmers who permitted the collection of blood samples.

\section{REFERENCES}

Blazak WF, Eldridge FE (1977) A Robertsonian translocation and its effect upon fertility in Brown Swiss cattle. J Dairy Sci 60, 1133-1142 
Di Berardino D, Iannuzzi L (1982) Detailed description of R-banded bovine chromosomes. J Hered 73, 434-438

Dunn HO, Kenny RM, Stone MH, Bendel S (1968) Cytogenetic and reproductive studies of XX/XY chimeric twin bulls. Proc 6th Int Congr Anim Reprod Paris 1968 2, 877-879

Foulley JL, Frebling J (1985) La translocation 1/29 chez les bovins: distribution, effets, procédure d'éradication. Bull Tech CRZV Theix INRA 62, 93-102

Gerneke WH (1969) Sterility in a bull, co-twin to a freemartin. JS Afr Vet Med Assoc 40(3), 279-283

Gustavsson I (1969) Cytogenetics, distribution and phenotypic effect of a translocation in Swedish cattle. Hereditas 63, 68-169

Gustavsson I (1979) Distribution and effect of the 1/29 Robertsonian translocation in cattle. $J$ Dairy Sci $62,825-835$

Kovacs A, Csukly S (1980) Effect of the 1/29 translocation upon fertility in Hungarian Simmentaler cattle. Proc 4th Eur Colloq Cytogenet Domest Anim Uppsala, June 10-12 1980. Swedish University of Agricultural Science, Uppsala, 35-43

Meyer EHH, De Boom HPA, Hofmeyr JH (1980) "Otter"-kalwers: 'n Oorerflike abnormaliteit in geregistreerde Friesbeeste in die RSA. Newslett: $S$ Afr Soc Anim Prod 19(1), 36

Moorhead PS, Nowell PC, Mellman WJ, Battips DN, Hungerford DA (1960) Chromosome preparations of leukocyte cultures from human peripheral blood. Exp Cell Res 20, 613-615

Nel ND, Harris EJ, Weiermans JE, Meyer EHH, Brix K (1985) A 1/29 chromosome translocation in Southern African Nguni cattle. The identification, occurrence and origin of the translocation. Génét Sél Evol 17(3), 293-302

Nel ND, Harris EJ, Weiermans JE, Meyer EHH (1988) The recent introduction of a 1/29 chromosome translocation in South African Brahman cattle. Génét Sél Evol 20(2), 239-246

Perryman LE (1979) Primary and secondary immune deficiencies in domestic animals. Adv Vet Sci Comp Med 23, 23-52

Popescu CP (1975) Essai d'identification des chromosomes bovins (Bos taurus L) à l'aide du marquage au 5-bromodeoxiuridine (BDR). 2 Eur Kolloq uber Zytogenetik (Chromosoncenpath in Veterinarmedizin Tierzucht und Saugetierkunde, Giessen. Deutsche veterinarmedizische Gesellschaft, 59-64

Popescu CP (1977) Les anomalies chromosomiques des bovins (Bos taurus L). État actuel des connaissances. Ann Génét Sél Anim 9, 463-470

Popescu CP (1982) Cytogenetics in domestic animal production. Proc 2nd World Congr Genetics Applied to Livestock Prod Madrid, Spain, Oct 4-8, 1982.6th Round Table, 375-384

Popescu CP, Ronne M, Cribiu EP, Boscher J (1982) The standardisation of the Rbanded karyotype in cattle (Bos taurus L). Proc 5th Eur Collog Cytogenet Domest Anim Milan-Gargnano, June 7-11, 1982, 172-190

Refsdal AO (1976) Low fertility in daughters of bulls with $1 / 29$ translocation. Acta Vet Scand 17, 190-195

Short RV, Smith J, Mann T, Evans EP, Hallett J, Fryer A, Hammerton JL (1969) Cytogenetic and endocrine studies of a freemartin heifer and its bull co-twin. Cytogenetics 8, 369-388 
Stafford MJ (1972) The fertility of bulls born co-twin to heifers. Vet Rec 90, 146-148 Swartz HA, Vogt DW (1983) Chromosome abnormalities as a cause of reproductive inefficiency in heifers. $J$ Hered $74,320-324$

Tandler J, Keller K (1911) Uber das Verhalten des Chorions bei verschiedengeschlechtlicher Zwillingsgravidität des Rindes und über die Morphologie des Genitales der weiblichen Tiere, welche einer solchen Gravidität enstammen. Deutsch Tierärzl Wschr 19, 148-149

Tschudi P (1984) Twelve years of cytogenetic investigation in AI bulls in Switzerland. Proc 6th Eur Colloq Cytogenet Domest Anim, Zurich, July 16-20, 1984, 40-42 Wriedt C, Mohr OL (1928) Amputated, a recessive lethal in cattle; with a discussion on the bearing of lethal factors on the principles of livestock breeding. $J$ Genet 20,187 